\title{
Dragonflies in Bawean Island Nature Reserve, Indonesia
}

\author{
ABDU ROHMAN*1, SETYO SULISTYONO², WAHYU NURYATI ${ }^{2}$, AHMAD ARIFANDY $^{2} \&$ \\ ARIS SETIYANTO2 \\ ${ }^{1}$ Biology Education, Faculty of Teacher Training and Education, University of Jember, 68121, Indonesia; \\ ${ }^{2}$ Biology Study Program, Faculty of Mathematics and Natural Sciences, Yogyakarta State University, 55281, \\ Indonesia \\ *Corresponding author: abdu.fkip@unej.ac.id \\ Received: 03 January $2020 \quad$ Accepted: 19 May $2020 \quad$ Published: 30 June 2020
}

\begin{abstract}
Bawaean Island is known for its endemic Bawa deer and other vertebrate species of mammals, avians and reptiles. However, little is known about the invertebrates, especially the Odonata (dragonflies) group. The aim of this study was to examine the variety of dragonflies on the Bawaean Island. The observation method was employed for data collection while the Shannon-Weinner Diversity Index was used for data analysis. A total of 23 dragonflies' species consisting of four families were collected throughout the study. These include Coegnagrionidae (6 species), Libellulidae (13 species), Platycnemididae (2 species) and Aeshnidae (1 species). Ischnura senegalensis is the most dominant species. The diversity index (absolute $\mathrm{H}$ index) shows a moderate level of diversity in Bawean Island, with a value of 1,007.
\end{abstract}

Keywords: Bawean Island, diversity, dragonflies, nature reserve

Copyright: This is an open access article distributed under the terms of the CC-BY-NC-SA (Creative Commons Attribution-NonCommercial-ShareAlike 4.0 International License) which permits unrestricted use, distribution, and reproduction in any medium, for non-commercial purposes, provided the original work of the author(s) is properly cited.

\section{INTRODUCTION}

Bawean Island is located at the Java Sea, approximately 150 kilometers north of Java Island. Geographically, the coordinates are $54^{0} 4^{\prime}-5^{0} 46^{\prime}$ LS AND $112^{\circ} 30^{\prime}-112^{\circ} 50^{\prime}$ BT with the covered area of around 725 hectares. The location of Bawean Island between Kalimantan and Java shows that this region has unique biogeography. The varied land topography includes bumpy, hilly to mountainous, and has a type of tropical lowland rainforest habitat (Badan Pusat Statistik Kabupaten Gresik, 2010).

One of the faunas on this island is dragonflies. In general, there are two sub-orders, namely Anisoptera and Zygoptera. Characteristics of the suborder Anisoptera has a fatter body, eyes attached, rear wings are more extensive than the front wings. The character that appears when perched spreads its wings horizontally. Characteristics of Suborder Zygoptera are slender bodies, non-sticky eyes, wing shapes that are almost identical between the front side and rear wing (Orr, 2003; Samways, 2008; Theiscinger \& Hawkins, 2008). Dragonflies are a group of insects related to aquatic (Boror et al., 1992).

Indonesia has around 750 species of dragonflies, which is abundant amount because Indonesia is a tropical region with a rich variety of habitats (Susanti, 1998). Around the world, a total of 6000 species of Odonata have been described. They are divided into one of two main suborders: Anisoptera (dragonflies, 11 Families) and Zygoptera (damselflies, 21 families) (Schorr et. al., 2008; Gullan \& Cranston, 2010).

Previous research was focused on the characteristics of dragonfly morphology and ecology (Lieftinck, 1954; Fraser, 1991; Watson et al., 1991; McPeek, 2008). Research at of Gunung Sewu Kars (Rohman, 2012), Menoreh Kars showed big different (Rachman \& Rohman, 2016) in variation of butterfly. Medium diversity index is applied in the Protection Forest area (Simatupang et al., 2019). Research on dragonflies in the Nusakambangan Island Nature Reserve shows that there are endemic species (Zaman et al., 2017). Therefore, the purpose of this study is to determine the diversity of dragonfly (Odonata) in the Bawean Island Nature Reserve. 


\section{MATERIALS AND METHODS}

\section{Study Sites}

The initial surveys were in January 2015 and a follow-up survey in 2018, 2019. Research location was on Bawean Island, Indonesia (Figure 1). Observation research method was used in this study. Data collection was conducted from 0700 to 1000 and 1500 to 1700 Western Indonesia time. Each plot consisted of three observation points. A total of 30 plots were conducted for data collection. The retrieval of data was conducted by recording and counting the number of species, and then entering the data into the observation table. Identification of the dragonfly was based on the identification manual by Theischinger (2006) and Watson et al. (1991). Climatic and edaphic measurements such as air temperature, light intensity, air humidity, wind speed, soil temperature and soil $\mathrm{pH}$ were also measured.

\section{Data Analysis}

Shannon-Wiener species diversity index according to Odum (1993) was used in this study.

\section{RESULTS AND DISCUSSION}

Thirty plots for dragonflies census were established at the Bawean Island Nature Reserve. A total of 23 species of dragonflies were collected at Bawean Island Nature Reserve (Table 1). The most abundant species comes from the Family Libellulidae, which consists of 13 species with 1399 individuals and of Orthetrum sabina, Diplacodes trivialis, Neurothemis ramburii, Crocothemis servilia, Macrodiplax cora, Potamarcha congener, Pantala flavescens, Tholymis tillarga, Neurothemis stigmatizans, Tramea transmarina, Macrodiplax cora, Potamarcha congener, Pantala plavescen, Tholymis fillarga, Neurothermis stigmatizans, Tramea transmarina, Agrionoptera insignis and Orthretic chrsis. Other dragonflies also found included Family Coegnagrionidae (6 species), Family Platycnemididae (2 species) and Family Aeshnidae with only one species, namely Anax guttatus. The species that cannot be identified was designated as code $\mathrm{F}$.

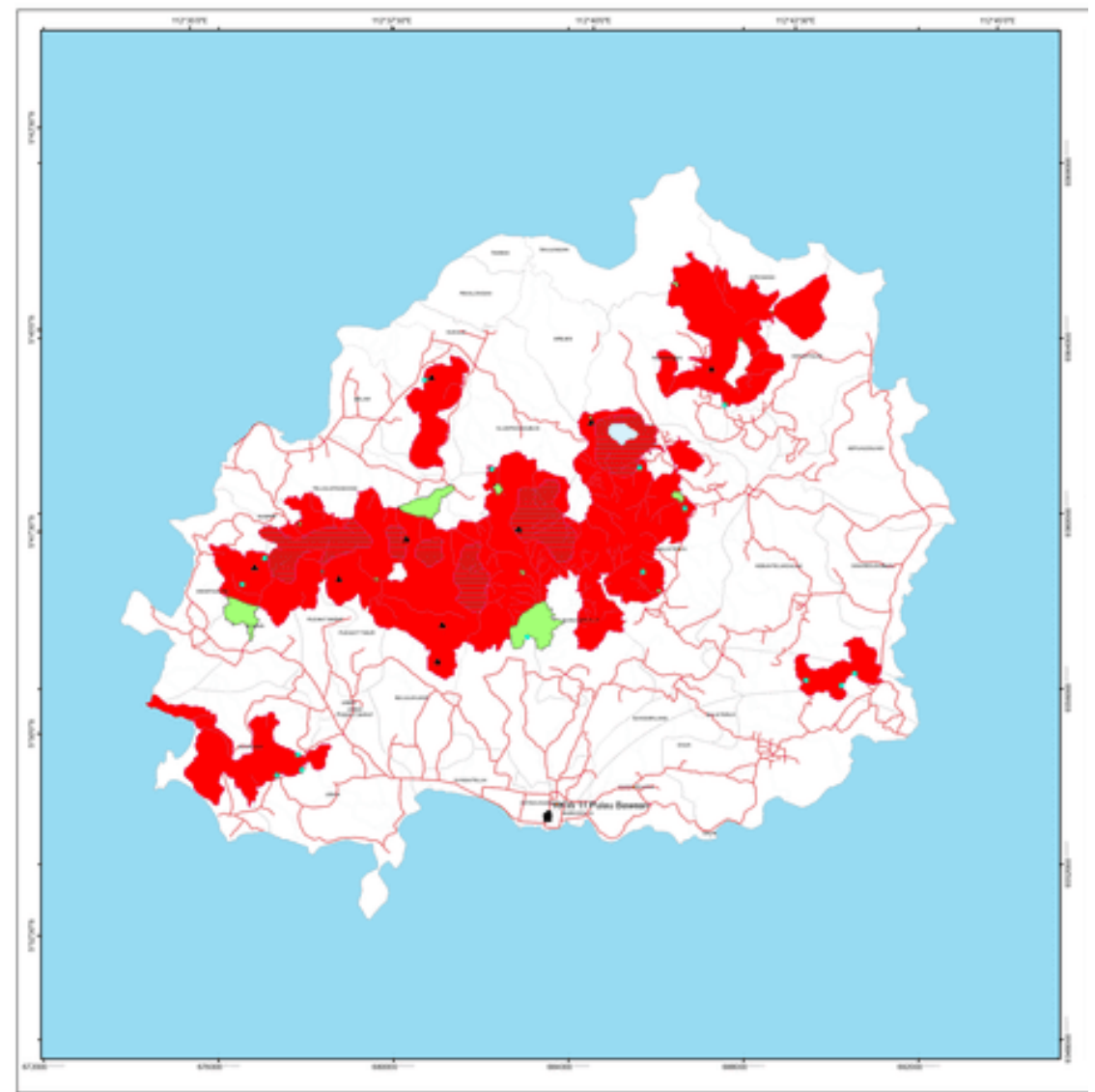

Figure 1. Map of Bawean Island Wildlife Reserve and Wildlife Conservation Area, Gresik Regency (Source: East Java Natural Resources Conservation Center) 
Of the four types of families found, the most abundant species in the family Libellulidae, while the fewest species are the Aeshnidae family. This shows that Family Libellulidae is the most existing species among others. Based on the results of Subagyo's research (2016), the swamp area is dominated by the family Libellulidae. Members of the family Libellulidae (Genus Orthetrum) are spread from residential areas to river flows in the mountains (Setyawati et al., 2017). Family Libellulidae and Coenagrionidae are the most common families based on the results of Odonata diversity inventory in Pampa Biome, Brazil (Junior et al., 2019). The Libellulidae family is the most species found in Gorewada International Bio-Park, India (Shende \& Patil, 2013).
Figure 2 shows that the highest percentage of dragonfly individuals was Ischnura senegalensis (17\%), followed by Orthetrum sabina (15\%), Diplacodes trivialis (13\%), Neurothermis ramburii $6 \%$, Crocothemis servilia (14\%), Macrodiplax cora (8\%), Tholymis tillarga (9\%) and so on. Ischnura senegalensis species showed the highest percentage of dragonfly individuals (17\%), followed by the second highest by Orthetrum sabina (15\%). The lowest percentage is in Orthetrum chrysis $(0.0005 \%)$. In Sharma and Joshi (2007), the results of the Libellulidae family were the most dominant with the highest percentage of Odonata diversity studies while the Coenagrionidae family with the second-highest in composition.

Table 1. Dragonflies (Odonata) in Bawean Island Nature Reserve

\begin{tabular}{|c|c|c|c|}
\hline No & Family & Species & Individual \\
\hline \multirow[t]{6}{*}{1} & Coegnagrionidae & Pseudagrion pruinosum & 8 \\
\hline & & Ischnura senegalensis & 362 \\
\hline & & Agriocnemis pygmaea & 190 \\
\hline & & Agriocnemis femina & 123 \\
\hline & & Pseudagrion rubriceps & 2 \\
\hline & & $\begin{array}{c}\text { Ceriagrion } \\
\text { coromandelianum }\end{array}$ & 2 \\
\hline \multirow[t]{13}{*}{2} & Libellulidae & Orthetrum sabina & 312 \\
\hline & & Diplacodes trivialis & 275 \\
\hline & & Neurothemis ramburii & 120 \\
\hline & & Crocothemis servilia & 297 \\
\hline & & Macrodiplax cora & 169 \\
\hline & & Potamarcha congener & 11 \\
\hline & & Pantala flavescen & 181 \\
\hline & & Tholymis tillarga & 8 \\
\hline & & Neurothemis stigmatizans & 10 \\
\hline & & Orthetrum chrysis & 1 \\
\hline & & Tramea transmarina & 7 \\
\hline & & Ceriagrion auraniicum & 5 \\
\hline & & Anax guttatus & 3 \\
\hline \multirow[t]{2}{*}{3} & Platycnemididae & Copera marginipes & 27 \\
\hline & & Prodasineura autumnalis & 4 \\
\hline \multirow[t]{2}{*}{4} & Aeshnidae & Agrionoptera insignis & 4 \\
\hline & & $F($ not yet identified $)$ & 3 \\
\hline Total & & 23 & 2124 \\
\hline
\end{tabular}




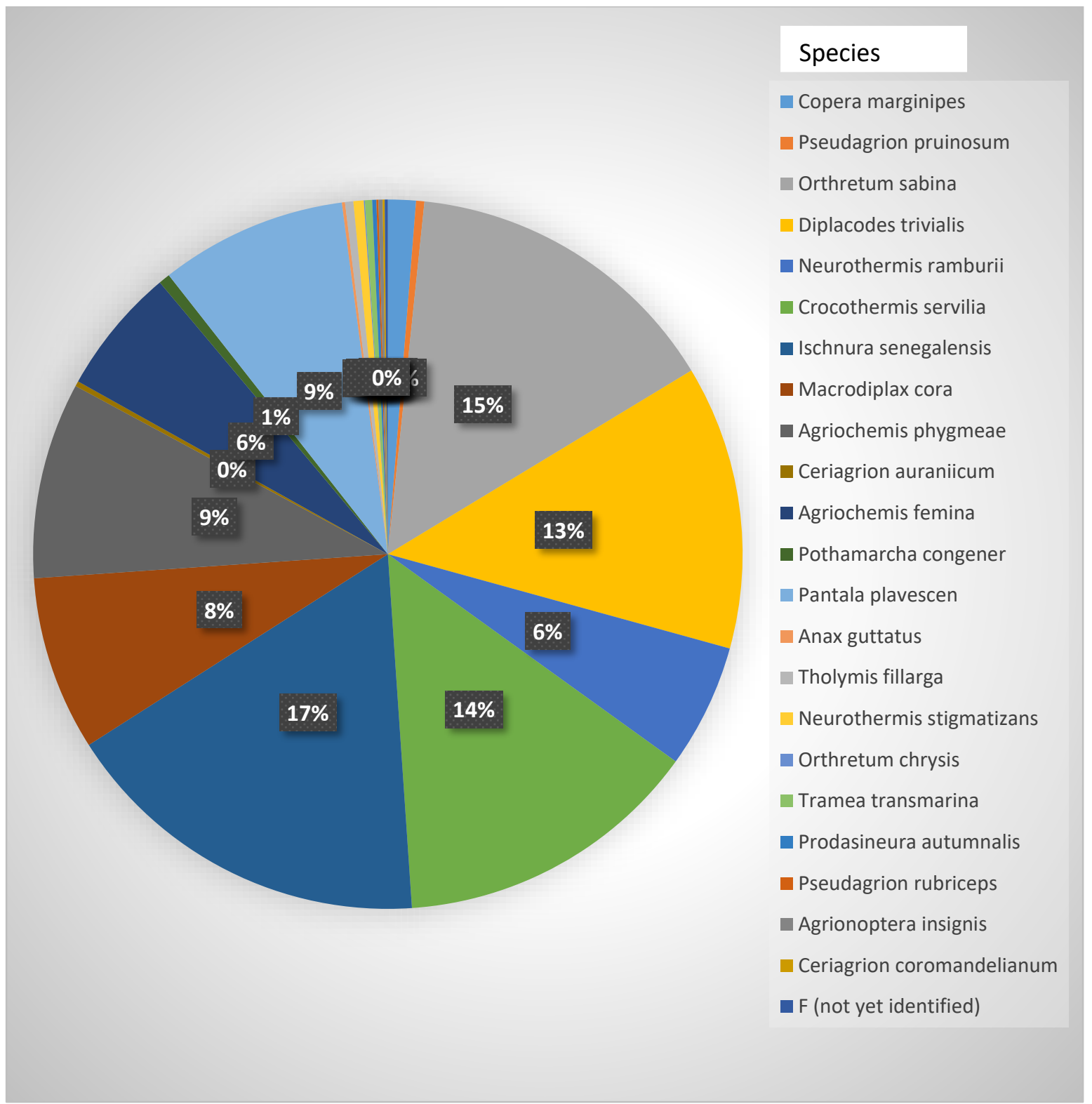

Figure 2. Percentage and diversity of Dragonflies (Odonata) in Bawean Island Nature Reserve. The $0 \%$ indicated the species with percentage lower than $1 \%$

A value analysis of the Shannon-Wiener Diversity Index data with a value of 1.007 ; these results indicate that the variation is moderate. According to Odum (1993), if the value of $\mathrm{H}$ index is more then 1 , it shows that the environment is in the right direction. According to Sharma and Joshi (2007), proper environmental conditions will increase the $\mathrm{H}$ index value. Based on the research of Wei-Yan (2008) the seasons such as dragonflies in spring, summer and autumn determine the variation of dragonflies, especially the Libellulidae family. Supporting a variety of dragonflies in the Wonoasri Resort Meru Betiri National Park and various Menoreh kars determine moderate fluctuations (Rachman et al., 2016; Hikmah,
2018).

There are several factors that affect the moderate diversity, including the surrounding environment and human activities. According to Nugrahani et al. (2014), the pollution due to the anthropogenic activities caused lower levels of diversity of dragonflies. In contrast, Johansson et al. (2019) pointed out several factors that influence the management of various types of vegetation are vital in maintaining regional biodiversity. Pereira $e t$ al. (2019) stated the balance between individuals with one another makes the balance between individuals with the state of the surrounding environment, with the atmosphere acting as a filter against the species. 


\section{CONCLUSION}

The most abundant species comes from the family Libellulidae, while the species of the Aeshnidae family members are the fewest. Index. ShannonWeiner diversity index $>1$ indicates that the environmental conditions in the Bawean Islands lead to suitable conditions for the survival of dragonflies.

\section{ACKNOWLEDGEMENTS}

We would like to thank East Java Conservation and Natural Resources Center, Bawean Nature Reserve, for supporting the data collection. Thanks also go to Mr. Sam Bawean, all the Bawean Nature Reserve Resort officers and the Bawean Island people for their assistance and hospitality. Finally, we would like to thank members of the Setyo brothers, Wahyu, Fandy, Aris, our lecturers and members of the Yogyakarta university community.

\section{REFERENCES}

Boror, D.J., Triplehorn, C.A. \& Johnson, N.F. (1996). Pengenalan pelajaran serangga, edisi VI. Yogyakarta: Gajah Mada University Press. Pp 240257.

Badan Pusat Statistik (BPS) Kabupaten Gresik. (2010). Kecamatan tambak dan Sangkapura dalam angka 2010. Badan Pusat Statistik: Gresik Jawa Timur. Pp 21.

Fraser, F.C. (1991). A handbook of the dragonflies of Australia with keys for the identification of all Species. Royal Zoological Society of New South Wales, Sydney.

Gullan, P.J. \& Cranston, P.S. (2010). The insects an outline of entomology (Fourth Edition). Australia: Department of Entomology, University of California. Pp 565-559.

Hikmah, A.N. (2018). Keanekaragaman spesies Odonata di Resort Wonoasri Taman Nasional Meru Betiri dan pemanfaatannya sebagai buku panduan lapangan. Jember. Universitas Jember. Pp 37-43

Johansson, F., Bini, L.M., Coiffard, P., Svanback, R., Wester, J. \& Heino, J. (2019). Environmental variables drive differences in the beta diversity of dragonfly assemblages among urban stormwater ponds. Ecological Indicators, 106: 105529.
Junior, M.D.N.G., Rakes, M., Pazini, J.B., Pasini, R.A., Garcia F.R.M. \& Grützmacher, A.D. (2019). The diversity of Odonata adults's at Pampa Biome from Brazil. Biologia Tropical, 67(1): 107-117.

Lieftinck, M.A. (1954). An annotated list of the Odonata of Java. Treubia. 22: Pp 269.

Nugrahani, M.P., Nazar, L., Makitan, T. \& Setiyono, J. (2014). Peluit tanda bahaya: capung indikator lingkungan panduan penilaian kualitas lingkungan melalui capung. Indonesian Dragonflies Society, Yogyakarta.

McPeek, M.A. (2008). Ecological factors limiting the distributions and abundances of Odonata. In Aguilar, A.C. (eds). Dragonflies and Damselflies: Model eorganisms for ecological and evolutionary Research. Oxford University Press Inc. New York. Pp 288.

Odum, E.P. (1993). Dasar-dasar ekologi. terjemahan: Tjahjono Samingan. Yogyakarta: UGM Press. Pp 696.

Orr, A.G. (2003). A guide to the dragonflies of Borneo: their identification and biology. Kota Kinabalu, Natural History Publications (Borneo).

Pereira, D.F.G, Junior, J.M.B.O. \& Juen, L. (2019). Environmental changes promote larger species of Odonata (Insecta) in Amazonian streams. Ecological Indicators, 98: 179-192.

Rachman, H.T. \& Rohman, A. (2016). Dragonflies diversity (Odonata) in Kars Menoreh Central JavaYogyakarta. International Journal of Advances in Agricultural \& Environmental Engineering, 3(2): 255-258.

Rohman, A. (2012). Keanekargaman jenis dan distribusi Capung (Odonata) di kawasan Kars Gnung Sewu Kecamatan Pracimantoro Kabupaten Wonogiri, Jawa Tengah. Yogyakarta: Universitas Negeri Yogyakarta.

Samways, M.J. (2008). Dragonflies dan Damselflies of South Africa. Sofia. Pensoft Publisher.

Schorr, M., Lindeboom, M. \& Paulson, D. (2008). World Odonata list. Tacoma, WA: Slater Museum of Natural History, University of Puget Sound. http://www.ups.edu/ x6140.xml.

Setyawati, S.M., Purwowidodo, Huda, M.M. \& Dewi, B.A. (2017). The Diversity of the dragonfly of 
Orthetrum Genus in Protected Area of Mount Prau, Central Java Indonesia. Journal of Natural Sciences and Mathematics Research, 3 (1): 28-235.

Sharma, G. \& Joshi, P.C. (2007). Diversity of Odonata (Insecta) from Dholbaha Dam (Distt. Hoshiarpur) in Punjab Shivalik, India. Journal of Asia-Pacific Entomology, 10(2): 177-180.

Shende V.A. \& Patil K.G. (2013). Diversity of dragonflies (Anisoptera) in Gorewada International Bio-Park, Nagpur, Central India. International Academy of Ecology and Environmental Sciences, 2(4): 200-207.

Simatupang, S., Syamsi, F., Rahmi \& Efendi, Y. (2019). Keanekaragaman Capung (Ordo: Odonata) di kawasan Hutan Lindung Duriangkang Tanjung Piayu Batam. SIMBIOSA, 8 (2): 158-167.

Subagyo, T.S. (2016). Keanekaragman Capung (Odonata) di Kawasan Rawa Jombor, Klaten, Jawa Tengah. Universitas Negeri Yogyakarta. Pp 98-105.

Susanti, S. (1998). LIPI, Seri panduan lapangan: Mengenai Capung. Bogor: Puslitbang Biologi-LIPI. Pp 7.
Susanto, P. (2000). Pengantar ekologi. Bogor: Departemen Pendidikan Nasional.

Theischinger, C. \& Hawkins, J. (2006). The complete field guide to dragonfly of Australia. Australia: CSIRO Publishing, Collingwood.

Wei-Yan, Y. (2008). Analysis on the flora of Libellulidae insects of Odonata in Lushan Area, Jiangxi Province and its diversity study. Journal of Anhui Agricultural Science, 2008-07.

Watson J.A.C, Theischinger, G. \& Abbey, H.M. (1991). The Australian dragonflies, A guide to identification distributions and habitats of Australian Odonata. Australia: CSIRO Australia, Canberra \& Melbourne.

Zaman, M.N., Yusuf, M., Romli, M., Syafii, I., Hardhaka, T., Faudi, B.F., Saikhu R.A., Ar Rouf, M.S., Adi, A., Laily, Z., Bimo, P.P. \& Yudo, P.M.H. (2017). Inventarisasi Keanekaan Anggota Ordo Odonata di Cagar Alam Nusakambangan Timur dan Sekitarnya Kabupaten Cilacap, Jawa Tengah. Seminar Nasional Pendidikan Biologi dan Saintek II, Pp 74-78. 